PROSIDING XXVII DAN KONGRES X PERHAPI 2018

\title{
KONSTRUKSI MODEL PERSAMAAN UNTUK PREDIKSI BIAYA PRODUKSI PEMINDAHAN LAPISAN TANAH PENUTUP MENGGUNAKAN ANALISIS REGRESI
}

\author{
Luviani Aldilla*, Aryanti Virtanti Anas*, Rini Novrianti Sutardjo Tui*, Sidiq \\ Faizal** dan Mutsammir** \\ *Departemen Teknik Pertambangan Universitas Hasanuddin, Makassar \\ **PT. Cipta Kridatama Site TMU, Kutai Kartanegara
}

\begin{abstract}
ABSTRAK
PT. Cipta Kridatama merupakan salah satu perusahaan kontraktor pertambangan di Provinsi Kalimantan Timur yang melakukan aktivitas penambangan lapisan tanah penutup batubara pada area IUPOP (Izin Usaha Penambangan Operasi Produksi) milik PT. Trisensa Mineral Utama (TMU). Kegiatan pemindahan lapisan tanah penutup merupakan salah satu tahapan kegiatan penambangan yang perlu dilakukan agar proses pengambilan batubara dapat terlaksana. Pemindahan lapisan tanah penutup dalam proses pengerjaannya menggunakan alat produksi. Penggunaan alat produksi sangat berpengaruh terhadap ketercapaian produksi dan biaya produksi. Biaya produksi yang dikeluarkan akan berpengaruh terhadap laba yang diperoleh perusahaan. Model persamaan biaya produksi dibutuhkan agar dapat melakukan prediksi terhadap biaya produksi untuk waktu yang akan datang. Data yang digunakan merupakan biaya produksi yang terdiri atas biaya kepemilikan dan biaya operasi bulan Januari 2018 hingga Februari 2018. Tujuan dari penelitian ini adalah menentukan model persamaan biaya produksi. Metode yang digunakan dalam penentuan model adalah analisis regresi. Dari analisis regresi linier sederhana dihasilkan dua model persamaan yaitu $\mathrm{Q}_{\mathrm{bp}}=49.027,215+0,803 \mathrm{D}_{\mathrm{p}}$ dengan depresiasi $\left(D_{p}\right)$ sebagai variabel bebas dan $Q_{b p}=43.670,377+0,197 B_{p}$ dengan biaya perbaikan dan perawatan $\left(B_{p}\right)$ sebagai variabel bebas. Model persamaan $Q_{b p}=43.615,936$ $+0,006 \mathrm{~B}_{\mathrm{bb}}+0,221 \mathrm{~B}_{\mathrm{p}}$ diperoleh dari analisis regresi linier berganda dengan biaya bahan bakar $\left(\mathrm{B}_{\mathrm{bb}}\right)$ dan biaya perbaikan dan perawatan $\left(\mathrm{B}_{\mathrm{p}}\right)$ sebagai variabel bebas.
\end{abstract}

Kata kunci: Tanah penutup, biaya produksi, regresi linier sederhana, regresi linier berganda.

\section{LATAR BELAKANG}

PT. Cipta Kridatama merupakan salah satu perusahaan kontraktor pertambangan di Provinsi Kalimantan Timur yang melakukan aktivitas penambangan lapisan tanah penutup (overburden) batubara pada area IUPOP (Izin Usaha Penambangan Operasi Produksi) milik PT. Trisensa Mineral Utama (TMU). PT. Cipta Kridatama melakukan kontrak dengan PT. Trisensa Mineral Utama selama tiga tahun dengan luas konsesi wilayah sebesar \pm 3.414 Ha (Cipta Kridatama, 2018). Daerah penambangan PT. Cipta Kridatama Site TMU terbagi menjadi tiga pit. Pit pertama yaitu Pit 5B21 aktif 
berproduksi hingga tanggal 3 Januari 2018, sedangkan pit kedua dan ketiga yaitu Pit

B3KL dan Pit B4D masih aktif berproduksi hingga saat ini.

Lingkup kerja utama yang dilakukan oleh PT. Cipta Kridatama yaitu pemindahan lapisan tanah penutup (overburden). Kegiatan pemindahan lapisan tanah penutup (overburden) merupakan salah satu tahapan kegiatan penambangan yang perlu dilakukan agar proses pengambilan batubara dapat terlaksana. Pengupasan dan pemindahan material lapisan tanah penutup (overburden) pada PT. Cipta Kridatama dilakukan dengan menggunakan alat produksi. Secara garis besar, alat produksi yang digunakan berdasarkan fungsinya yaitu alat muat, alat angkut, dan alat support. Proses penambangan pada umumnya menggunakan enam pasangan alat (fleet) dalam satu lokasi kerja. Satu pasangan alat (fleet) terdiri atas satu alat muat, empat alat angkut, dan alat support berupa bulldozer dan grader. Penggunaan alat produksi sangat berpengaruh terhadap ketercapaian produksi dan biaya produksi yang dikeluarkan. Biaya produksi akan menjadi bahan pertimbangan bagi perusahaan untuk menentukan perencanaan anggaran yang akan berpengaruh terhadap harga jual sebuah produk setelah mempertimbangkan keuntungan yang diinginkan.

Biaya produksi merupakan akumulasi dari semua biaya yang dibutuhkan dalam proses produksi pada kegiatan penambangan. Biaya produksi terdiri atas biaya kepemilikan (owning cost) dan biaya operasi (operating cost). Biaya produksi yang dikeluarkan akan berpengaruh terhadap keuntungan yang diperoleh. Keuntungan merupakan pendapatan yang diperoleh dari selisih antara biaya produksi dan pendapatan (revenue). Selain itu perhitungan biaya produksi sangat penting hal ini karena pay back period dalam pertambangan membutuhkan waktu yang cukup lama (Rudenno, 2009). Berdasarkan hal tersebut maka prediksi biaya produksi diperlukan untuk perencanaan anggaran biaya produksi.

Prediksi yang dilakukan umumnya didasarkan pada data masa lalu yang kemudian dianalisis dengan menggunakan metode analisis tertentu (Sungkawa dan Megasari, 2011). Analisis untuk menentukan model persamaan yang bertujuan untuk memperhitungkan serta memprediksi suatu nilai ini disebut dengan analisis korelasi dan analisis regresi. Analisis korelasi digunakan untuk mengetahui hubungan antar variabel, sedangkan analisis regresi selain untuk mengetahui besarnya pengaruh antarvariabel, juga untuk memprediksi nilai satu variabel atau lebih variabel (Supranto, 2005). Tujuan pada penelitian ini adalah mengonstruksi model persamaan biaya produksi pemindahan lapisan tanah penutup dengan pendekatan analisis regresi.

\section{METODE PENELITIAN}

Metode yang digunakan pada penelitian ini mencakup beberapa hal yang berkaitan langsung dengan teknis pelaksanaan penelitian yang dilakukan. Metode penelitian dilakukan di PT. Cipta Kridatama Site TMU merupakan suatu teknik atau cara untuk mencari, memeroleh, mengumpulkan serta mencatat data yang dapat dipergunakan untuk menganalisis faktor-faktor yang berhubungan dengan pokok-pokok permasalahan dan menyusun hasil penelitian.

\section{Pengambilan Data}

Pengambilan data dilakukan selama dua bulan di Departemen Production Planning and Control (PPNC) PT. Cipta Kridatama Site TMU. Data yang digunakan merupakan data keuangan pada bulan Januari 2018 hingga Februari 2018 dengan jumlah data sebanyak 59 data. Data yang diambil berupa data:

Total biaya produksi 

membeli alat-alat berat dan sebesar biaya yang harus diterima pada saat umur alat sudah tidak ekonomis lagi. Biaya kepemilikan terdiri atas depresiasi $\left(\mathrm{D}_{\mathrm{p}}\right)$, biaya sewa $\left(\mathrm{B}_{\mathrm{s}}\right)$, project overhead expenses $\left(\mathrm{P}_{\mathrm{oe}}\right)$, health, safety, environtment (HSE) and community development $\left(\mathrm{H}_{\mathrm{se}}\right)$, dan biaya lain-lain $\left(\mathrm{B}_{\mathrm{l}}\right)$.

b. Biaya operasi atau operating cost adalah biaya yang terkait dengan pemeliharaan dan administrasi. Biaya operasi terdiri atas gaji karyawan $\left(\mathrm{G}_{\mathrm{k}}\right)$, biaya bahan bakar $\left(\mathrm{B}_{\mathrm{bb}}\right)$, dan biaya perawatan dan perbaikan $\left(\mathrm{B}_{\mathrm{p}}\right)$.

\section{Pengolahan dan Analisis Data}

Pengolahan dan analisis data yang dilakukan pada penelitian ini menggunakan analisis regresi. Analisis regresi adalah alat yang banyak digunakan di banyak bidang studi, karena dapat dengan mudah dimodelkan menggunakan asumsi sederhana. Analisis regresi berkenaan dengan studi ketergantungan dari suatu variabel yang disebut variabel tidak bebas (dependent variable), pada satu atau lebih variabel yaitu variabel yang menerangkan (Anas et al., 2013). Analisis regresi bertujuan untuk memperkirakan dan atau meramalkan nilai rata-rata dari variabel tidak bebas apabila nilai variabel yang menerangkan sudah diketahui (Supranto, 2005). Analisis regresi terbagi atas dua yaitu analisis regresi linier sederhana dan analisis regresi linier berganda. Analisis regresi linier sederhana adalah analisis yang digunakan apabila hanya memiliki satu variabel bebas, sedangkan analisis regresi linier berganda adalah analisis yang digunakan apabila memiliki lebih dari satu variabel bebas.

Analisis regresi dilakukan dengan menggunakan bantuan Software Statistic Package Software System (SPSS). Analisis regresi diawali dengan menginput data ke dalam SPSS dan memformulasikan masalah ke dalam bentuk matematik, yaitu dengan menentukan variabel bebas dan variabel tidak bebas. Data-data tersebut diuji dengan menggunakan uji asumsi klasik yang terdiri atas uji normalitas, uji heterokesdastisitas, uji otokorelasi, dan uji multikolinearitas. Jika telah memenuhi uji asumsi klasik maka dilakukan uji simultan (uji F) dan uji parsial (uji t) serta melihat besar koefisien determinasi dan koefisien korelasi. Setelah itu diperoleh model persamaan regresi. Model persamaan ini akan diuji dengan menggunakan uji validasi Mean Absolute Percentage Error (MAPE) yang berguna untuk mengindikasi besar kesalahan dalam peramalan atau prediksi dibandingkan dengan nilai nyata atau aktual.

\section{HASIL PENELITIAN}

\section{Analisis Regresi Linier Sederhana}

Analisis regresi linier sederhana dilakukan pada setiap variabel bebas yang digunakan dengan tingkat kepercayaan sebesar 95\%. Persamaan model yang diperoleh diuji menggunakan uji statistik untuk menentukan variabel bebas yang dapat digunakan mengonstruksi model.

\section{Gaji Karyawan}

Analisis regresi linier sederhana dengan menggunakan variabel bebas gaji karyawan membentuk model regresi, yaitu:

$0,217 \mathrm{G}_{\mathrm{k}}$ $55.979,308$ 
dimana:

$\mathrm{Q}_{\mathrm{bp}} \quad=\quad$ Biaya produksi

$\mathrm{G}_{\mathrm{k}}=$ Gaji karyawan

Nilai koefisien dari variabel bebas bernilai -0,217 yang berarti setiap kenaikan gaji karyawan sebesar $1 \%$ menyebabkan total biaya produksi akan menurun sebesar US $\$ 0,217$. Uji F dan uji t yang dilakukan menunjukkan nilai signifikansi sebesar 0,630 . Nilai signifikansi tersebut lebih besar dari $\alpha(0,05)$, artinya variabel tersebut tidak berpengaruh signifikan terhadap variabel tidak bebas. Oleh karena itu, variabel gaji karyawan tidak dapat digunakan karena gaji karyawan berbanding terbalik terhadap biaya produksi dan tidak berpengaruh signifikan terhadap biaya produksi.

\section{Biaya Bahan Bakar}

Analisis regresi linier sederhana dengan menggunakan variabel bebas biaya bahan bakar membentuk model regresi, yaitu:

$402 \mathrm{~B}_{\mathrm{bb}}$

$48.473,921$

0 ,

dimana:

$\mathrm{Q}_{\mathrm{bp}}=$ Biaya produksi

$\mathrm{B}_{\mathrm{bb}}=$ Biaya bahan bakar

Nilai koefisien dari variabel bebas bernilai 0,402 yang berarti setiap kenaikan biaya bahan bakar sebesar $1 \%$ menyebabkan total biaya produksi akan meningkat sebesar US $\$ 0,402$, tetapi uji simultan atau uji $\mathrm{F}$ dan uji parsial atau uji t yang dilakukan menunjukkan nilai signifikansi sebesar 0,137 . Nilai signifikansi tersebut lebih besar dari $\alpha(0,05)$, artinya variabel tersebut tidak berpengaruh signifikan terhadap variabel tidak bebas. Berdasarkan hal tersebut variabel biaya bahan bakar tidak dapat digunakan karena biaya bahan bakar tidak berpengaruh signifikan terhadap biaya produksi.

\section{Project Overhead Expenses}

Analisis regresi linier sederhana dengan menggunakan variabel bebas project overhead expenses membentuk model regresi, yaitu:

$0,932 \mathrm{P}_{\mathrm{oe}}$
Qbp
$=$
$60.059,636$

dimana:

$\mathrm{Q}_{\mathrm{bp}} \quad=\quad$ Biaya produksi

$\mathrm{P}_{\mathrm{oe}} \quad=\quad$ Project overhead expenses

Uji $\mathrm{F}$ dan uji t yang dilakukan pada model menghasilkan nilai signifikansi sebesar 0,110. Nilai signifikansi tersebut lebih besar dari $\alpha(0,05)$, artinya variabel tersebut tidak berpengaruh signifikan terhadap variabel tidak bebas. Persamaan 3 menunjukkan bahwa nilai koefisien dari variabel bebas bernilai -0,932 yang berarti setiap kenaikan project overhead expenses sebesar $1 \%$ menyebabkan total biaya produksi akan menurun sebesar US \$0,932. Oleh karena itu, variabel project overhead expenses tidak dapat digunakan karena berbanding terbalik terhadap biaya produksi dan tidak berpengaruh signifikan terhadap biaya produksi.

\section{Health, Safety, Enviroment (HSE) and Community Development}


Analisis regresi linier sederhana dengan menggunakan variabel bebas health, safety, enviroment (HSE) and community development membentuk model regresi, yaitu:

$\begin{array}{lll}\mathrm{Q}_{\mathrm{bp}} & = & 56.696,544\end{array}$

dimana:

$\mathrm{Q}_{\mathrm{bp}} \quad=\quad$ Biaya produksi

$\mathrm{H}_{\mathrm{se}} \quad=\quad$ Health, safety, enviroment (HSE) and community development

Nilai koefisien dari variabel bebas bernilai $-9,900$ yang berarti setiap kenaikan health, safety, enviroment (HSE) and community development sebesar 1\% menyebabkan total biaya produksi akan menurun sebesar US $\$ 9,900$. Uji F dan uji t yang dilakukan menunjukkan nilai signifikansi sebesar 0,267. Nilai signifikansi tersebut lebih besar dari $\alpha(0,05)$, artinya variabel tersebut tidak berpengaruh signifikan terhadap variabel tidak bebas. Oleh karena itu, variabel health, safety, enviroment (HSE) and community development tidak dapat digunakan karena berbanding terbalik terhadap biaya produksi dan tidak berpengaruh signifikan terhadap biaya produksi.

\section{Biaya Sewa}

Analisis regresi linier sederhana dengan menggunakan variabel bebas biaya sewa membentuk model regresi, yaitu:

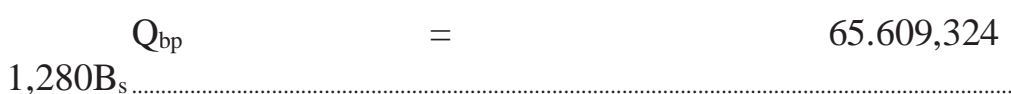

dimana:

$\mathrm{Q}_{\mathrm{bp}} \quad=\quad$ Biaya produksi

$\mathrm{B}_{\mathrm{s}} \quad=\quad$ Biaya sewa

Model yang digunakan telah memenuhi syarat dalam uji asumsi klasik, sedangkan untuk uji $\mathrm{F}$ dan uji t yang dilakukan menghasilkan nilai signifikansi sebesar 0,004 . Nilai signifikansi tersebut lebih kecil dari $\alpha(0,05)$, artinya variabel tersebut berpengaruh signifikan terhadap variabel tidak bebas, tetapi nilai koefisien variabel bebas yang digunakan bernilai negatif yaitu $-1,280$. Hal ini berarti bahwa setiap kenaikan biaya sewa sebesar $1 \%$ menyebabkan total biaya produksi akan menurun sebesar US \$1,280. Oleh karena itu, variabel biaya sewa tidak dapat digunakan karena berbanding terbalik terhadap biaya produksi.

\section{Biaya Lain-lain}

Analisis regresi linier sederhana dengan menggunakan variabel bebas biaya lainlain membentuk model regresi, yaitu: $4,074 \mathrm{~B}_{1 \ldots}$

dimana:

$$
\mathrm{Q}_{\mathrm{bp}} \quad=\quad \text { Biaya produksi }
$$

$\mathrm{B}_{1} \quad=\quad$ Biaya lain-lain

Variabel biaya lain-lain tidak dapat digunakan karena berbanding terbalik terhadap biaya produksi. Hal ini ditunjukkan oleh nilai koefisien dari variabel bebas bernilai $-4,074$ yang berarti setiap kenaikan biaya lain-lain sebesar $1 \%$ maka total biaya produksi akan menurun sebesar US $\$ 4,074$. Uji F dan uji t yang dilakukan memeroleh 
nilai signifikansi sebesar 0,000 . Nilai signifikansi tersebut lebih kecil dari $\alpha(0,05)$, artinya variabel tersebut berpengaruh signifikan terhadap variabel tidak bebas.

\section{Depresiasi}

Analisis regresi linier sederhana dengan menggunakan variabel bebas depresiasi membentuk model regresi, yaitu:

$0,803 \mathrm{D}_{\mathrm{p}}$

$=$

$49.027,215$

dimana,
$\mathrm{Q}_{\mathrm{bp}} \quad=\quad$ Biaya produksi
$\mathrm{D}_{\mathrm{p}} \quad=\quad$ Depresiasi

Grafik yang menunjukkan model persamaan dapat dilihat pada Gambar 1.

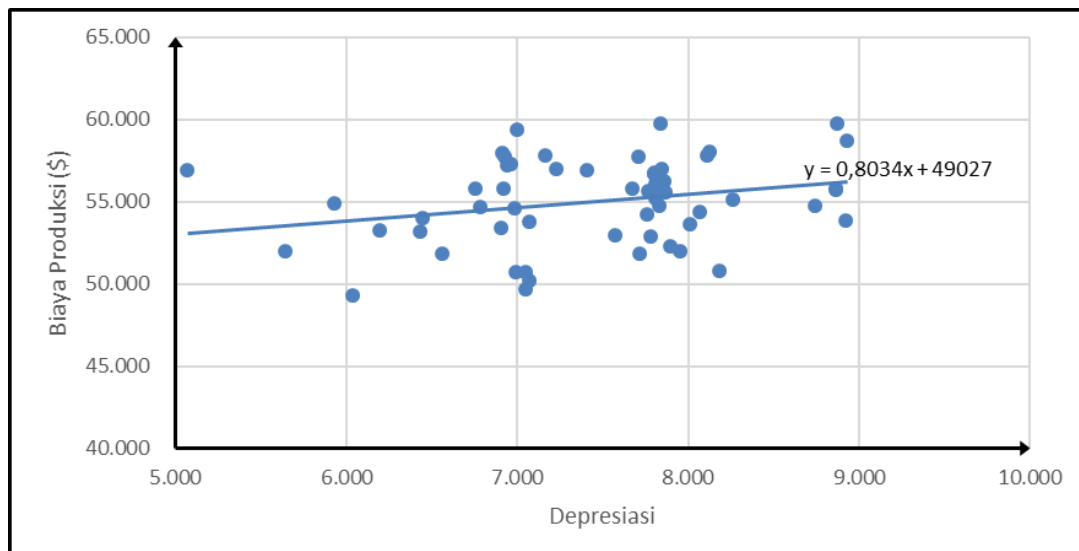

Gambar 1. Grafik model persamaan menggunakan variabel bebas depresiasi

Rata-rata nilai MAPE untuk hasil prediksi adalah 0,195\%. Nilai yang diperoleh menggambarkan bahwa model yang digunakan memiliki kinerja sangat bagus karena nilai MAPE yang dimiliki kurang dari 10\%, sehingga disimpulkan kesalahan dalam prediksi dapat ditolerir. Grafik perbandingan antara biaya aktual dan biaya prediksi dapat dilihat pada Gambar 2.

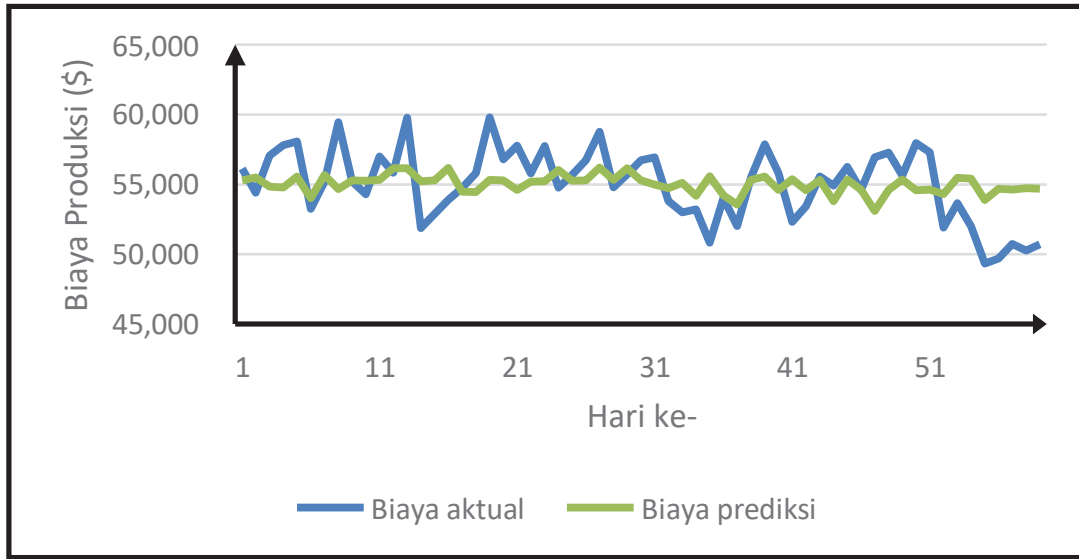

Gambar 2. Grafik perbandingan antara biaya aktual dan biaya prediksi dengan variabel bebas depresiasi 


\section{Biaya perbaikan dan perawatan}

Analisis regresi linier sederhana dengan menggunakan variabel bebas biaya perbaikan dan perawatan membentuk model regresi, yaitu:

$0,197 \mathrm{~B}_{\mathrm{p}}$

dimana,

$\mathrm{Q}_{\mathrm{bp}} \quad=$ Biaya produksi

$\mathrm{B}_{\mathrm{p}} \quad=$ Biaya perbaikan dan perawatan

Grafik yang menunjukkan model persamaan dapat dilihat pada Gambar 3.

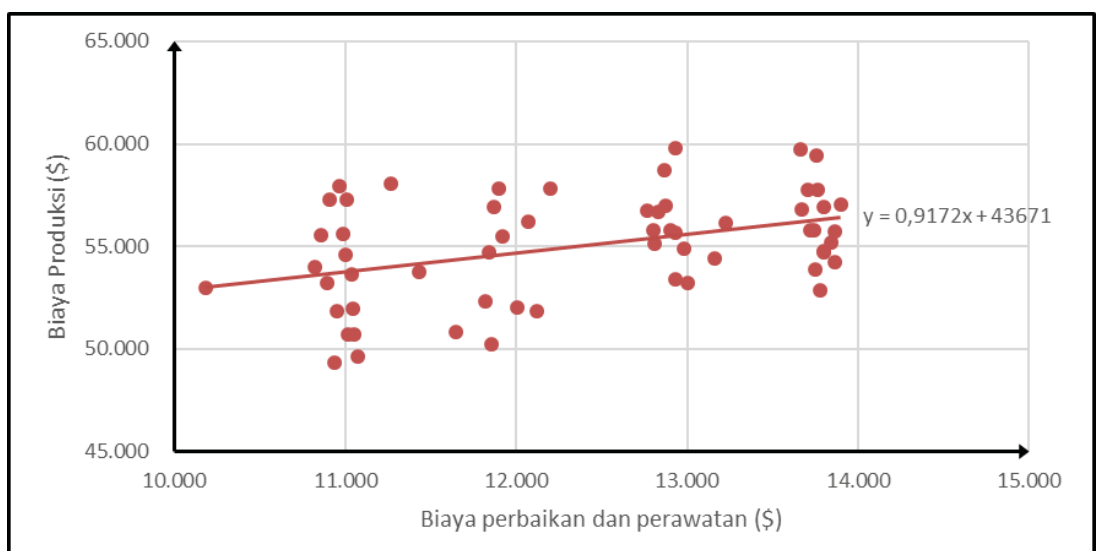

Gambar 3. Grafik model persamaan menggunakan variabel bebas biaya perbaikan dan perawatan

Model persamaan yang diperoleh dari variabel bebas biaya perbaikan dan perawatan, telah memenuhi syarat dalam uji statistik. Model persamaan dari variabel depresiasi dapat digunakan karena koefisien dari tiap variabel berbanding lurus dengan biaya produksi. Hasil pendugaan nilai koefisien variabel bebas, uji statistik, dan MAPE dapat dilihat pada Tabel 2.

Tabel 2. Hasil pendugaan nilai koefisien variabel bebas, uji statistik, dan MAPE

\begin{tabular}{lllll}
\hline $\begin{array}{l}\text { Variabel tidak } \\
\text { bebas }\end{array}$ & Variabel bebas & Notasi & $\begin{array}{l}\text { Nilai koefisien } \\
\text { variabel bebas }\end{array}$ & Uji statistik \\
\hline Biaya produksi & & $\mathrm{Q}_{\mathrm{bp}}$ & & $\mathrm{R}=0,409$ \\
& $\begin{array}{l}\text { Intersep } \\
\text { Biaya bahan bakar }\end{array}$ & $\mathrm{B}_{\mathrm{bb}}$ & 0,197 & $\mathrm{R} \mathrm{R}^{2}=0,167$ \\
& & & & $\mathrm{Sig} . \mathrm{F}=0,001$ \\
& & & $\mathrm{MAPE}=16,022 \%$ \\
\hline
\end{tabular}

Nilai MAPE untuk hasil prediksi dengan menggunakan Persamaan 8 adalah $16,022 \%$. Nilai yang diperoleh menggambarkan bahwa model yang digunakan memiliki kinerja bagus karena nilai MAPE yang dimiliki terletak di antara $10 \%$ dan 20\%, sehingga disimpulkan kesalahan dalam prediksi dapat ditolerir. Grafik perbandingan antara biaya aktual dan biaya prediksi dapat dilihat pada Gambar 4. 


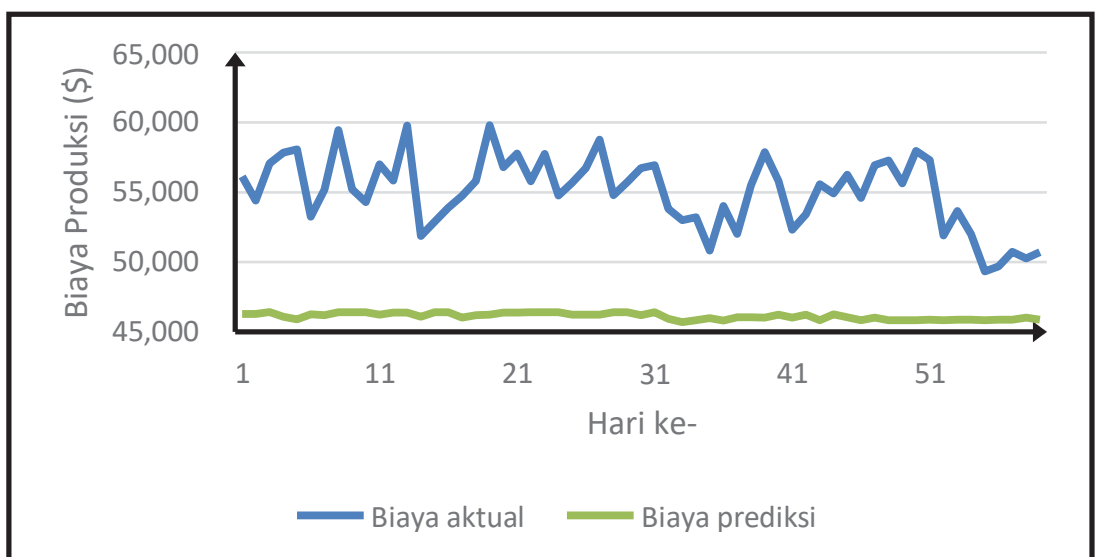

Gambar 4. Grafik perbandingan antara biaya aktual dan biaya prediksi dengan variabel biaya bebas perbaikan dan perawatan

Model persamaan dengan variabel bebas biaya perbaikan dan perawatan memiliki nilai koefisien korelasi sebesar 0,409 menunjukkan hubungan antara variabel bebas dan variabel tidak bebas adalah hubungan yang cukup berarti, hubungan ini berdasarkan. Nilai koefisien determinasi yang diperoleh untuk depresiasi adalah $16,7 \%$, yang berarti $83,3 \%$ variabel tidak bebas dipengaruhi oleh variabel bebas yang lain. Nilai MAPE yang diperoleh dari perbandingan antara biaya aktual dan prediksi sebesar 16,022\%. Besar penyimpangan yang diperoleh berdasarkan MAPE masih bisa ditolerir, namun jika persamaan ini dibandingkan dengan model persamaan lainnya penyimpangan yang dimiliki adalah yang paling besar.

\section{Analisis Regresi Linier Berganda}

Analisis regresi linier berganda dilakukan pada setiap variabel bebas yang digunakan dengan tingkat kepercayaan sebesar 95\%. Persamaan model yang diperoleh diuji menggunakan uji statistik untuk menentukan variabel bebas yang dapat digunakan mengonstruksi model.

\section{Regresi linier berganda menggunakan semua variabel bebas}

Analisis regresi linier berganda dengan menggunakan semua variabel bebas membentuk model regresi, yaitu: $2,908 \mathrm{H}_{\mathrm{se}}-$

$$
\mathrm{Q}_{\mathrm{bp}}=83.848,566+0,150 \mathrm{G}_{\mathrm{k}}-0,103 \mathrm{~B}_{\mathrm{bb}}-0,388 \mathrm{D}_{\mathrm{p}}-1,091 \mathrm{~B}_{\mathrm{s}}+0,221 \mathrm{~B}_{\mathrm{p}}+
$$

$$
2.794 \mathrm{P}_{\mathrm{oe}}
$$

dimana,

$\begin{array}{lll}\mathrm{Q}_{\mathrm{bp}} & = & \text { Biaya produksi } \\ \mathrm{G}_{\mathrm{k}} & = & \text { Gaji karyawan } \\ \mathrm{B}_{\mathrm{bb}} & = & \text { Biaya bahan bakar } \\ \mathrm{D}_{\mathrm{p}} & = & \text { Depresiasi } \\ \mathrm{B}_{\mathrm{s}} & = & \text { Biaya sewa } \\ \mathrm{B}_{\mathrm{p}} & = & \text { Biaya perbaikan dan perawatan } \\ \mathrm{H}_{\mathrm{se}} & = & \text { Health, safety, enviroment }(\mathrm{HSE}) \text { and community development } \\ \mathrm{P}_{\mathrm{oe}} & = & \text { Project overhead expenses } \\ \mathrm{B}_{\mathrm{l}} & = & \text { Biaya lain-lain }\end{array}$


Model persamaan yang diperoleh dari penggunaan semua variabel bebas, telah memenuhi syarat dalam uji statistik. Hasil pendugaan nilai koefisien variabel bebas dan uji statistik dapat dilihat pada Tabel 3.

Tabel 3. Hasil pendugaan nilai koefisien variabel bebas, uji statistik, dan MAPE

\begin{tabular}{lllll}
\hline $\begin{array}{c}\text { Variabel tidak } \\
\text { bebas }\end{array}$ & \multicolumn{1}{c}{ Variabel bebas } & Notasi & $\begin{array}{r}\text { Nilai koefisien } \\
\text { variabel bebas }\end{array}$ & \multicolumn{1}{c}{ Uji statistik } \\
\hline Biaya produksi & Q & & $\mathrm{r}=0,796$ \\
& $\begin{array}{l}\text { Intersep } \\
\text { Gaji karyawan }\end{array}$ & $\mathrm{G}_{\mathrm{k}}$ & $83.848,566$ & $\mathrm{R}=0,634$ \\
& $\begin{array}{l}\text { Biaya bahan bakar } \\
\text { Depresiasi }\end{array}$ & $\mathrm{B}_{\mathrm{bb}}$ & 0,150 & $\mathrm{Sig} . \mathrm{F}=0,000$ \\
& $\begin{array}{l}\mathrm{D}_{\mathrm{p}} \\
\text { Biaya sewa }\end{array}$ & $-0,103$ & \\
& $\begin{array}{l}\text { Biaya perawatan } \\
\text { dan perbaikan }\end{array}$ & $\mathrm{B}_{\mathrm{p}}$ & $-0,388$ & \\
& $\begin{array}{l}\text { Health, safety, } \\
\text { enviroment (HSE) }\end{array}$ & $\mathrm{H}_{\mathrm{se}}$ & 0,221 & \\
& $\begin{array}{l}\text { and community } \\
\text { development }\end{array}$ & $\mathrm{P}_{\mathrm{oe}}$ & 2,908 & \\
& $\begin{array}{l}\text { Project overhead } \\
\text { expenses }\end{array}$ & $\mathrm{B}_{1}$ & -2.794 & \\
& Biaya lain-lain & & $-5,447$ & \\
\hline
\end{tabular}

Model persamaan yang diperoleh dari analisis regresi berganda dengan menggunakan semua variabel telah memenuhi semua syarat dari uji statistik. Model persamaan ini tidak bisa digunakan. Hal ini disebabkan adanya nilai negatif dari koefisien variabel bebas. Nilai negatif berarti variabel yang digunakan berbanding terbalik terhadap biaya produksi, sedangkan hubungan antara total biaya produksi dan variabel bebas yang memengaruhinya adalah berbanding lurus. Artinya, kenaikan atau penurunan nilai variabel bebas diikuti dengan kenaikan atau penurunan nilai total biaya produksi. Oleh karena itu, model pada persamaan dianggap tidak memenuhi syarat, sehingga diperlukan modifikasi model persamaan dengan cara melakukan pengurangan atau reduksi variabel bebas.

\section{Regresi linier berganda dengan Mereduksi Variabel Bebas}

Reduksi variabel bebas dilakukan untuk memeroleh model persamaaan regresi yang memenuhi uji dan validasi dari model. Reduksi variabel bebas dilakukan dengan cara mengeliminasi variabel bebas yang memiliki nilai signifikansi uji t lebih besar dari 0,05 dan menggunakan variabel bebas yang memiliki biaya aktual terbesar. Setelah dilakukan beberapa percobaan dengan cara mengeliminasi beberapa variabel bebas, maka diperoleh variabel bebas yang digunakan untuk mengkonstruksi model persamaan baru adalah biaya bahan bakar serta biaya perbaikan dan perawatan.

Analisis regresi linier berganda setelah pengurangan variabel bebas membentuk model regresi, yaitu:

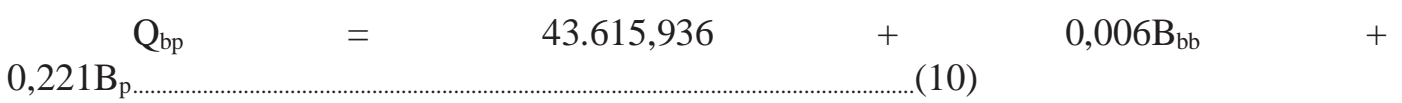

dimana,

$\begin{array}{lll}\mathrm{Q}_{\mathrm{bp}} & = & \text { Biaya produksi } \\ \mathrm{B}_{\mathrm{bb}} & = & \text { Biaya bahan bakar } \\ \mathrm{B}_{\mathrm{p}} & = & \text { Biaya perbaikan dan perawatan }\end{array}$


Model persamaan yang diperoleh setelah pengurangan variabel bebas, telah memenuhi syarat dalam uji statistik. Hasil pendugaan nilai koefisien variabel bebas dan uji statistik dapat dilihat pada Tabel 4.

Tabel 4. Hasil pendugaan nilai koefisien variabel bebas, uji statistik, dan MAPE

\begin{tabular}{|c|c|c|c|c|}
\hline $\begin{array}{c}\text { Variabel tidak } \\
\text { bebas }\end{array}$ & Variabel bebas & Notasi & $\begin{array}{l}\text { Nilai koefisien } \\
\text { variabel bebas }\end{array}$ & Uji statistik \\
\hline \multirow[t]{4}{*}{ Biaya produksi } & & $\mathrm{Q}_{\mathrm{bp}}$ & & \multirow{4}{*}{$\begin{array}{l}R=0,409 \\
R^{2}=0,167 \\
d W=1,313 \\
\text { Sig.F }=0,006 \\
\text { MAPE }=0,185 \%\end{array}$} \\
\hline & Intersep & & $43.615,936$ & \\
\hline & Biaya bahan bakar & $\boldsymbol{\nu} \mathrm{bb}$ & 0,006 & \\
\hline & $\begin{array}{l}\text { Biaya perawatan } \\
\text { dan perbaikan }\end{array}$ & $\mathrm{B}_{\mathrm{p}}$ & 0,221 & \\
\hline
\end{tabular}

Nilai MAPE untuk hasil prediksi adalah 0,185\%. Nilai yang diperoleh menggambarkan bahwa model yang digunakan memiliki kinerja sangat bagus karena nilai MAPE yang dimiliki kurang dari 10\%, sehingga disimpulkan kesalahan dalam prediksi dapat ditolerir. Grafik perbandingan antara biaya aktual dan biaya prediksi dapat dilihat pada Gambar 5.

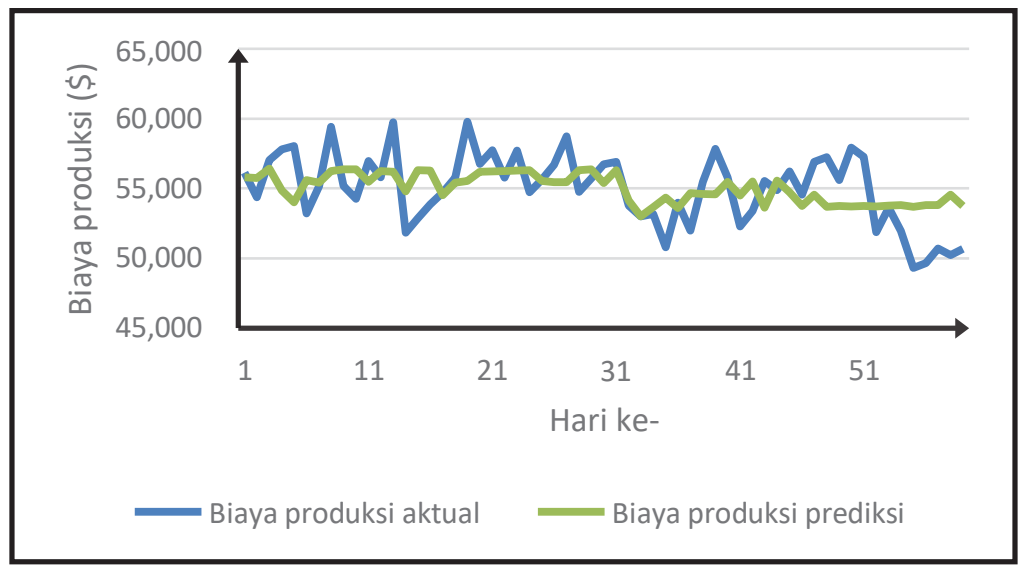

Gambar 5. Grafik perbandingan antara biaya aktual dan biaya prediksi

Tabel 4 menunjukkan hasil pendugaan berdasarkan analisis regresi linier berganda. Model pada Persamaan 10 telah memenuhi syarat dari uji statistik, sehingga model persamaan dapat digunakan. Semua koefisien yang ada pada persamaan bernilai positif yang menunjukkan setiap variabel bebas yang digunakan berbanding lurus terhadap variabel tidak bebas. Nilai koefisien korelasi dan koefisien determinasi adalah 0,409 dan 0,167. Nilai koefisien korelasi menunjukkan hubungan antara variabel bebas dan variabel tidak bebas adalah hubungan yang cukup berarti. Nilai koefisien determinasi menunjukkan bahwa variabel bebas yang digunakan menjelaskan variasi dari variabel tidak bebas sebesar $16,7 \%$ dan sisanya dipengaruhi oleh variabel lain.

\section{KESIMPULAN}

Kesimpulan yang diperoleh dari hasil penelitian ini yaitu:

1. Analisis regresi linier sederhana menghasilkan dua model persamaan yang dapat digunakan untuk memprediksi biaya produksi pemindahan lapisan tanah penutup. Model persamaan dengan menggunakan variabel bebas depresiasi $\left(\mathrm{D}_{\mathrm{p}}\right)$ adalah $\mathrm{Q}_{\mathrm{bp}}$ 
$=49.027,215+0,803 \mathrm{D}_{\mathrm{p}}$ dan variabel bebas biaya perbaikan dan perawatan $\left(\mathrm{B}_{\mathrm{p}}\right)$ adalah $\mathrm{Q}_{\mathrm{bp}}=43.670,377+0,197 \mathrm{~B}_{\mathrm{p}}$.

2. Analisis regresi linier berganda menghasilkan model persamaan yang dapat digunakan untuk memprediksi biaya produksi pemindahan lapisan tanah penutup dengan cara mereduksi variabel bebas yang digunakan. Variabel bebas yang diperoleh setelah reduksi variabel bebas adalah biaya bahan bakar $\left(\mathrm{B}_{\mathrm{bb}}\right)$ dan biaya perbaikan dan perawatan $\left(\mathrm{B}_{\mathrm{p}}\right)$ dengan model persamaan $\mathrm{Q}_{\mathrm{bp}}=43.615,936+$ $0,006 \mathrm{~B}_{\mathrm{bb}}+0,221 \mathrm{~B}_{\mathrm{p}}$.

\section{UCAPAN TERIMA KASIH}

Penulis mengucapkan terima kasih kepada segenap karyawan dan staf PT. Cipta Kridatama Site atas kesempatan dan bimbingan yang diberikan selama melaksanakan penelitian.

\section{DAFTAR PUSTAKA}

Anas, A.V., Suriamihardja, D.A., Pallu, S., Irfan, U.R. 2013. Supply and Demand of Jeneberang River Aggregate Using Multiple Regression Model. International Journal of Innovation and Applied Studies, Vol. 3, No. 3, pp. 774-780.

PT Cipta Kridatama. 2018. Departemen Planning Production and Control. PT. Cipta Kridatama Site TMU.

Rudenno, V. 2009. Mining Valuation Book, $3^{\text {rd }}$ Edition. Melbourne, Australia: Wrightbooks.

Sungkawa, I., Megasari, R.T. 2011. Penerapan Ukuran Ketepatan Nilai Ramalan Data Deret Waktu dalam Seleksi Model Peramalan Volume Penjualan PT Satriamandiri Citramulia. ComTech, Vol.2, No. 2.

Supranto, J. 2005. Ekonometri Buku Pertama. Jakarta: Ghalia Indonesia. 
